\title{
Optimization of Embodied Energy in Bridge Construction
}

\author{
Subrata Aditama K.A. Uda ${ }^{1,2,}$, Mochamad Agung Wibowo ${ }^{3}$, Jati Utomo Dwi Hatmoko ${ }^{3}$ \\ ${ }^{1} \mathrm{PhD}$ Student, Department of Civil Engineering, Diponegoro University, Semarang, Indonesia \\ ${ }^{2}$ Department of Civil Engineering, Faculty of Engineering, Palangka Raya University, Palangka Raya, Indonesia \\ ${ }^{3}$ Department of Civil Engineering, Faculty of Engineering, Diponegoro University, Semarang, Indonesia
}

Received August 6, 2020; Revised October 27, 2020; Accepted November 1, 2020

\section{Cite This Paper in the following Citation Styles}

(a): [1] Subrata Aditama K.A. Uda, Mochamad Agung Wibowo, Jati Utomo Dwi Hatmoko, "Optimization of Embodied Energy in Bridge Construction," Civil Engineering and Architecture, Vol. 8, No. 6, pp. 1167 - 1177, 2020. DOI: 10.13189/cea.2020.080602.

(b): Subrata Aditama K.A. Uda, Mochamad Agung Wibowo, Jati Utomo Dwi Hatmoko (2020). Optimization of Embodied Energy in Bridge Construction. Civil Engineering and Architecture, 8(6), 1167 - 1177. DOI: 10.13189/cea.2020.080602.

Copyright $\odot 2020$ by authors, all rights reserved. Authors agree that this article remains permanently open access under the terms of the Creative Commons Attribution License 4.0 International License

\begin{abstract}
Construction activities consume a lot of energy and produce emissions which damage the environment. Furthermore, bridge construction is one of the infrastructure buildings which consume the largest amount of energy due to the materials, transportation, and heavy equipment used in the process. It is, however, important to reduce the energy consumed at each stage of the construction in order to ensure a decrease in the environmental impacts. This study was conducted to calculate the total energy consumed in a bridge project and the process was optimized to reduce the amount of energy used in the initiation, design, construction, and operation activities. Data were collected through observations of 3 bridge projects in the Central Java region, Indonesia. Furthermore, a reinforced concrete type of bridge was used and the amount of energy at each stage was determined by multiplying the volume of materials, electricity, and fuel used with the energy coefficient. The results showed the total energy generated in bridge projects 1,2 , and 3 was 21,870,543.14 MJ, 16,616,641.09 MJ, and 8,753,712.69 MJ. These values were decreased by $6.55 \%, 8.73 \%$, and $3.45 \%$ respectively after optimization. This means the optimization process was able to effectively minimize the energy used in each activity of the project and also has a positive impact on the implementation of green construction, especially for bridge projects.
\end{abstract}

Keywords Infrastructure, Project Life Cycle, Bridge Projects, Energy Optimization, Embodied Energy

\section{Introduction}

Global warming and extreme climate change are caused by environmental pollution and this has led to the implementation of several steps to preserve living things such as the Kyoto Agreement and the $21^{\text {st }}$ Conference of Parties [1]. Meanwhile, construction sector is one of the producers of emissions and pollution from waste materials as evident in the $36 \%$ of energy and $40 \%$ of emissions produced by the sector and reported by UNEP [2]. China, India, Japan, Indonesia, and Canada contribute the highest quantity of embodied energy and carbon emission in the world [3] while United States of America generates 39\% of its emissions from buildings, material production, and construction processes but have lesser percentage in transportation and industrial activities [4]. It is, however, possible to reduce the emissions in the construction sector by applying green building concept to limit its impact on the environment [5].

Green infrastructure is a concept which focuses on the spatial planning and environmental impacts of construction activities [6]. Meanwhile, green road and bridge is the application of green infrastructure constructing roads and bridges as observed in several European and American countries. However, the guidelines and rating system for green bridge assessments provide information on the position of greening implemented in projects [7] and this is necessary considering the positive impact of the concept on the environment and ecosystem of life [8].

Construction projects in Indonesia are dominated by 
infrastructural buildings which were valued at Rp 442 trillion in 2018 and placed in the $50^{\text {th }}$ position globally based on the competitive index [9]. This means there is the possibility of higher energy consumption and emissions in the country. Therefore, actions are required to reduce these emissions through the implementation of environmental-friendly and sustainable construction processes.

\section{Bridge Construction in Project Life-Cycle Concept}

\subsection{Project Life Cycle}

The project life cycle is a series of developmental activities which include the initiation, design, construction, and maintenance/operation stages of a building. There is, however, a wide variation in these activities based on the type and characteristics of the project and the organization involved. Project Life Cycle (PLC) is part of the Building Life Cycle (BLC) concept which is more focused on the activities conducted during construction as shown in figure 1.

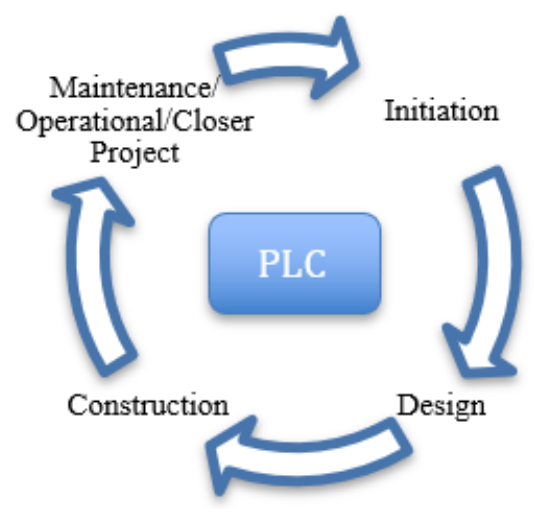

Figure 1. The Project Life Cycle Concept

\section{Initiation Phase}

A project is usually initiated based on the idea of the owner and this serves as the main factor which determines the design and construction. The owner's commitment to the implementation of standards and building specifications which prioritize the green building concept in the contract document is essential to achieve an environmentally-friendly building [10]. The activities associated with the initiation stage include project feasibility studies, plan drawings and specifications, Term of Reference (TOR), Bill of Quantity (BQ), and tenders [11].

\section{Design Phase}

The design phase is an important part of achieving the building shape desired by the owner. This stage is significant due to the effect of image and type of material on a building. Moreover, the ability of planners highly depends on its expertise in defining the owner's project scope and those with poor translational skills usually experience changes in the initial or source of the project, repeated work, schedule delays, and cost overruns. The activities of this stage include the formation of project structure and team, detailed design drawings, the scope of work, technical data, project schedules, worker schedules, material/spending schedules, procedures, and other details. The initial steps to minimize environmental impact are required to be integrated into this planning stage due to its significant importance to the success of the next stage [11]

\section{Construction Phase}

The construction phase is the stage for the project implementation and it involves the supply of materials, tools and labor, as well as the implementation of actual construction activities based on the designs approved by the owner. It is the phase for the culmination of development activities using several resources. Meanwhile, the choice of materials, tools, and personnel influences the sustainability of the construction process and quality of the building. Therefore, construction methods and technologies such as Building Information Management (BIM) are used by contractors to control and evaluate each activity in order to reduce time, ensure cost efficiency, and minimize materials used to produce lesser wastes. The use of higher tools, materials, labor, and working capital than required during production have also been reported to have the ability to cause inefficiency and poor building quality. This, therefore, means project quality is highly dependent on workmanship, construction management, completeness, quality of contract documents, and field supervisors [11].

\section{Maintenance/Operational/Closer Phase}

The operational and maintenance phase is the final stage of a project. This includes handing over the project to the owner after a feasibility test to guarantee its safety for users. The final site inspection needs to be conducted with the owner's representatives, planning consultants, supervising consultants, and contractors. Operation manual and handover minutes are, however, one of the outputs of this phase [11].

\subsection{Embodied and Operational Energies on Project Life Cycle (PLC)}

Embodied and operational energies occur in each building's life cycle. Embodied energy is consumed during project activities as a whole and it includes energy used up in producing and moving materials, transportation activities, and use of tools during construction and building maintenance activities [12]. Meanwhile, operational 
energy occurs during building operational activities such as the electricity used, heating, and air conditioning energies and are mostly sourced from fossil fuels. Operational energy has been discovered by some researchers to be the biggest contributor with $80 \%$ to total energy consumption in a building's life cycle [13].

British Standards Institution (BSEN) 15978:2011 also showed that embodied energy consumption starts from the beginning of material production to the end of the building construction while operational energy only occurs when the building is being used as indicated in figure 2 .

\subsection{Bridge Construction}

A bridge is a structural building used in connecting roads between regions which are cut off due to geographical conditions such as rivers, ravines, valleys, and roads [14]. The planning process of building bridges has a high level of difficulty and the five important aspects are the bridge structure, material type, size and aesthetics, existing conditions, and environmental factors [15]. The inclusion of aesthetics and environmental factors provides additional value to the function of the bridge by making it an icon for a region or country it is located [16].

\subsubsection{Concrete Bridge Structure}

The bridge structure is divided into three main components which are superstructure, substructure, and foundation. Superstructure components are deck and wearing surface, girder, curb, expansion joint, handrail, parapet, and approach. Meanwhile, the elements of the substructure include the bearing, pier, and column or pedestal, abutment, and retaining wall while the components of the foundation are footing and pile [17]. The typical components of a concrete bridge are presented in figures 3 and 4.

\begin{tabular}{|c|c|c|c|c|c|c|c|c|c|c|c|c|c|c|c|c|}
\hline \multicolumn{16}{|c|}{ BUILDING LIFE CYCLE } & \multirow{3}{*}{$\begin{array}{c}\text { ADDITIONAL } \\
\text { INFORMATION } \\
\text { POTENTIAL } \\
\text { BENEFIT \& LOAD } \\
\text { D }\end{array}$} \\
\hline \multicolumn{3}{|c|}{ PRODUCT STAGE } & \multicolumn{2}{|c|}{\begin{tabular}{|c|} 
CONSTRUCTION \\
STAGE \\
\end{tabular}} & \multicolumn{7}{|c|}{ USE STAGE } & \multicolumn{4}{|c|}{ END OF LIFE STAGE } & \\
\hline A1 & A2 & A3 & A4 & A5 & B1 & B2 & B3 & B4 & B5 & B6 & B7 & C1 & C2 & C3 & C4 & \\
\hline 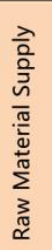 & 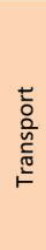 & 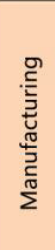 & 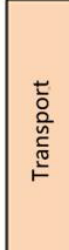 & 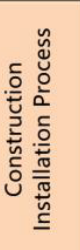 & 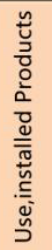 & 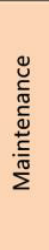 & 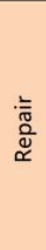 & 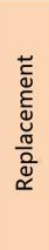 & 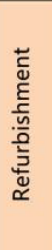 & 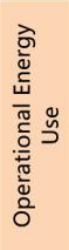 & 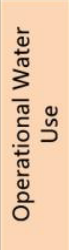 & 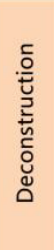 & 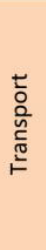 & 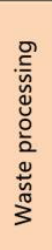 & $\begin{array}{l}\overline{\widetilde{\sigma}} \\
\overline{0} \\
\overline{0} \\
\overline{0}\end{array}$ & 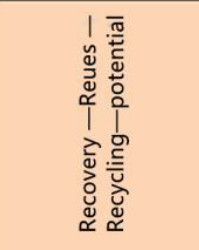 \\
\hline \multicolumn{10}{|c|}{ Embodies Energy } & \multirow{2}{*}{\multicolumn{2}{|c|}{$\begin{array}{c}\text { Operational } \\
\text { Energy }\end{array}$}} & \multicolumn{5}{|c|}{ Embodied Energy } \\
\hline & & & & & & & & & & & & & & & & Operational Energy \\
\hline
\end{tabular}

Figure 2. The Boundaries of Embodied Energy and Operational [18] 


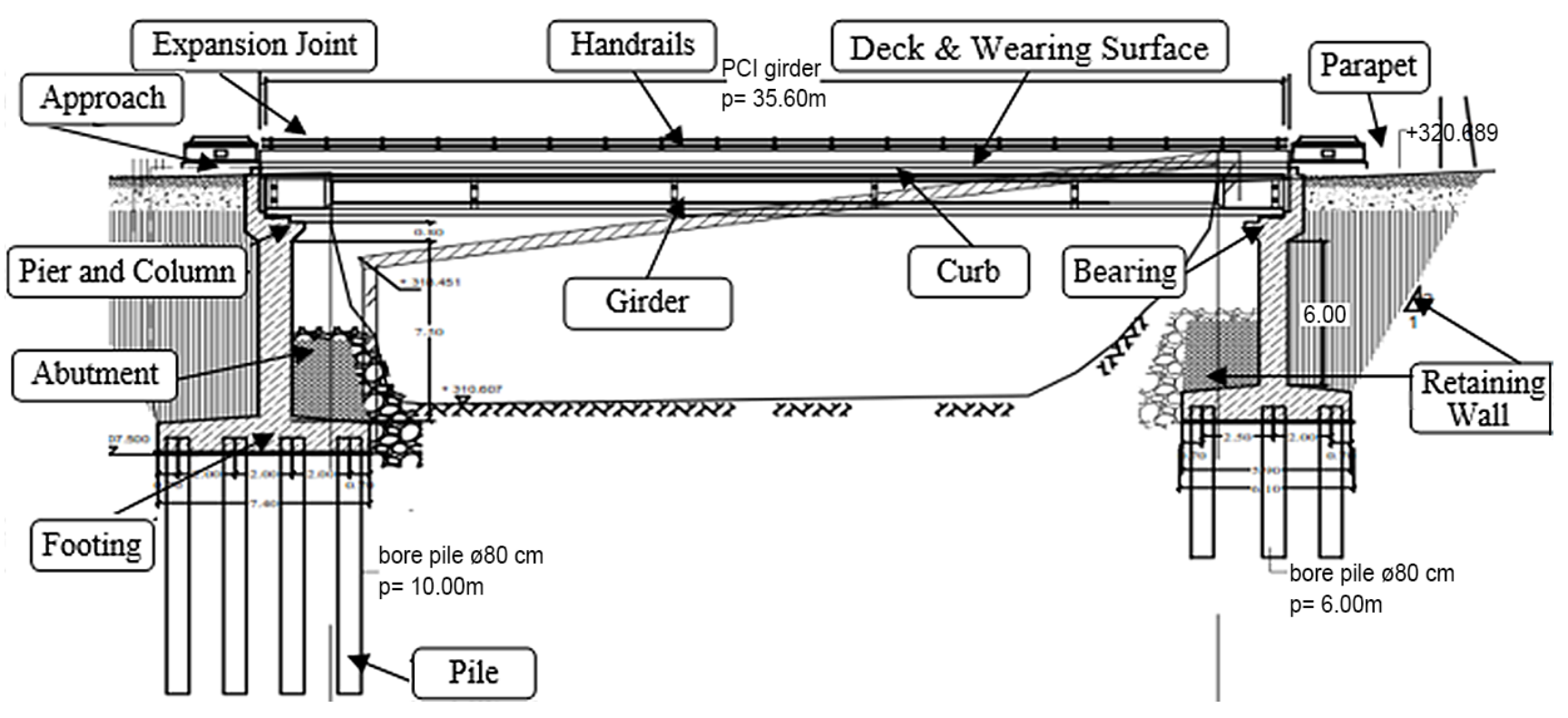

Figure 3. The Typical Cross Section of Concrete Bridge Structure

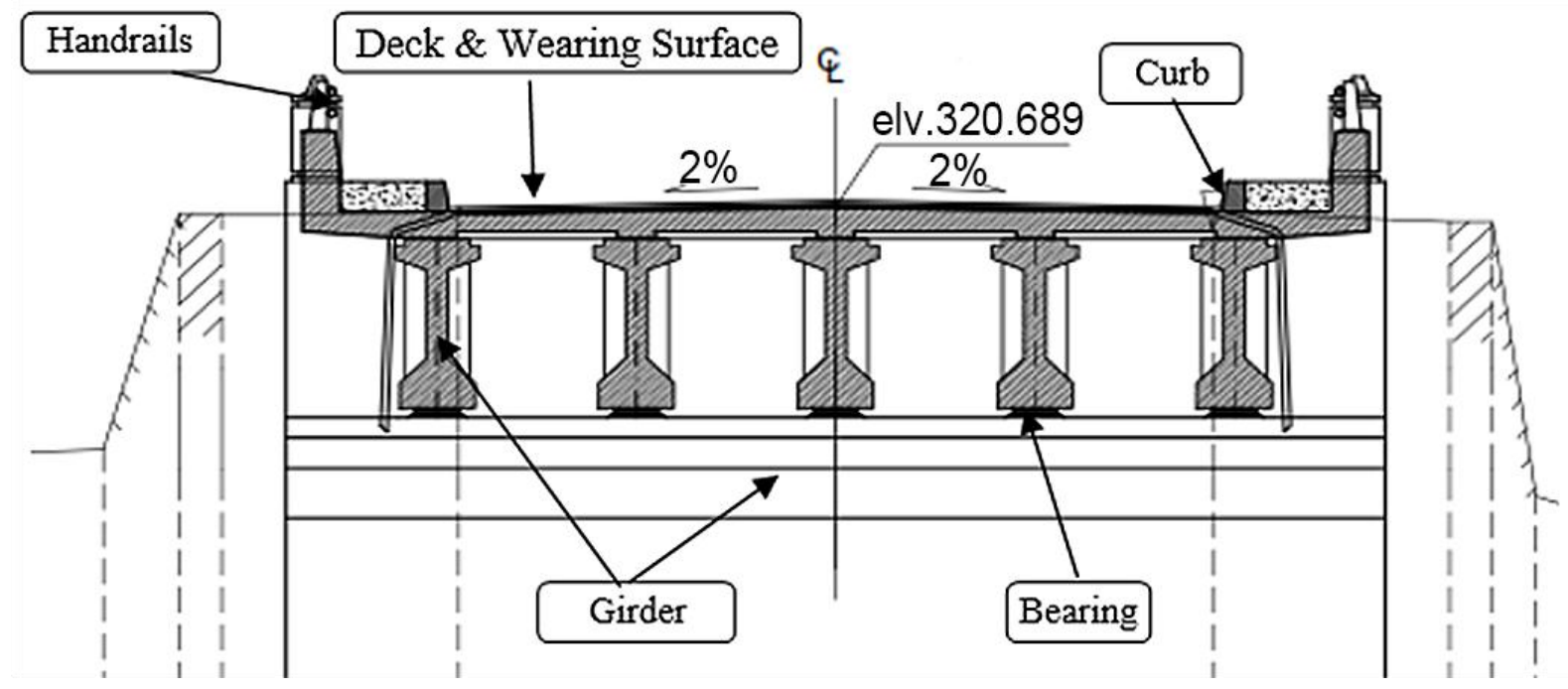

Figure 4. The Typical Cross Section of Concrete Bridge Structure 
Table 1. Several energy optimization efforts based on Project Life Cycle (PLC)

\begin{tabular}{|c|c|c|}
\hline PLC Phase & Optimization of energy and emission activities & References \\
\hline Initiation & $\begin{array}{l}\text { - } \\
\text { - } \\
\text { - } \\
\text { - Thelicy to reuse structures in old buildings, especially in government projects. } \\
\text { Making policies on Energy Performance Development Guidelines for building } \\
\text { construction. }\end{array}$ & {$[10],[18],[20],[23],[26]$} \\
\hline Design & $\begin{array}{l}\text { - } \\
\text { - } \quad \text { Fptimizing the layout and building structure system plan } \\
\text { - } \\
\text { - } \\
\text { - } \\
\text { - } \quad \text { Optimizimizing building service component life } \\
\text { - } \quad \text { Reusing building parts and elements } \\
\text { - } \quad \text { The application of innovative materials with lower environmental impact } \\
\text { Building planning with consideration for ease of demolition } \\
\text { Planning process which minimizes the use of high energy consuming materials } \\
\text { such as iron, steel, and concrete }\end{array}$ & $\begin{array}{c}{[3],[5],[6],[7]} \\
{[8],[10],[12]} \\
{[13],[15],[16],[20],[22],} \\
23],[25],[26]\end{array}$ \\
\hline Construction & 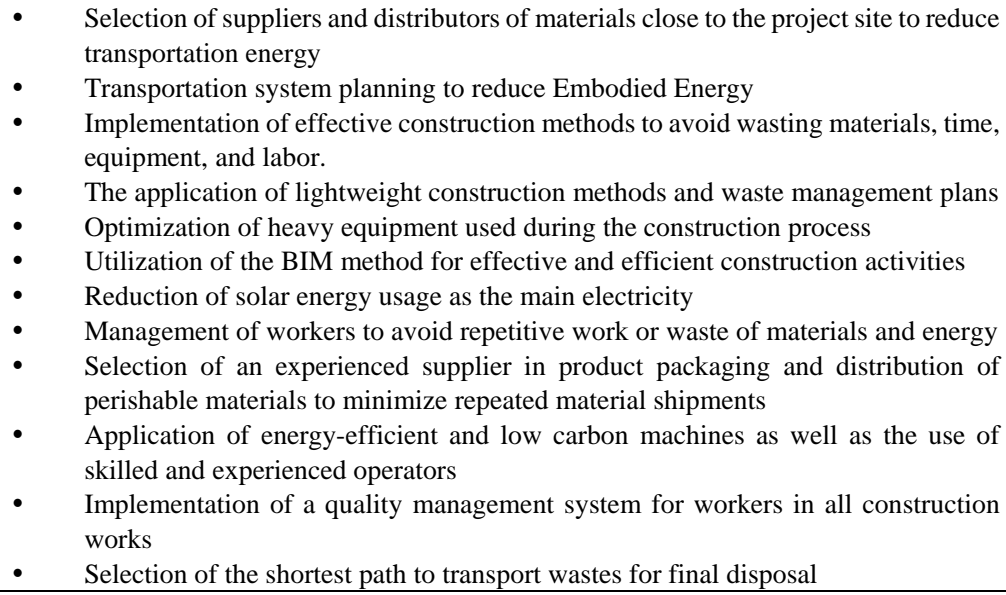 & $\begin{array}{c}{[3],[5],[6],[7]} \\
{[8],[10],[12],} \\
{[13],[19],[20],[21],[22],} \\
{[23],[24],[25],[26]}\end{array}$ \\
\hline $\begin{array}{c}\text { Maintenance/Op } \\
\text { erational/ Closer } \\
\text { Project }\end{array}$ & $\begin{array}{l}\text { - Application of environmentally friendly alternative energy } \\
\text { - } \quad \text { Implementation of renewable energy sources in building operations } \\
\text { Application of energy-efficient sensor systems for lighting, elevators, heating, } \\
\text { ventilation, and air conditioning } \\
\text { Application of environmentally friendly and energy-efficient materials for building } \\
\text { repair and maintenance activities }\end{array}$ & $\begin{array}{c}{[5],[7],[12],} \\
{[13],[20],[23]}\end{array}$ \\
\hline
\end{tabular}

\subsubsection{Energy efficiency based on Project Life Cycle (PLC)}

Energy can be optimized by ensuring efficiency in each construction activity that is expected to directly reduce emissions and impact on the environment. Moreover, government policies and regulations which prioritize environmental factors in every development process have been reported to have the ability to strengthen the efforts to reduce carbon emissions [10]. Previous study also showed that the energy used during construction activities produces emissions which contribute to global warming [19].

This is, however, reduceable in construction activities starting from the initiation to the building operation stage by using environmentally friendly materials and construction methods [20]. The energy optimization efforts related to PLCs which are obtained from previous literature are presented in table 1 .

This study aimed to calculate the amount of energy consumed in three types of bridge projects at different locations and sizes but the same concrete bridge construction method. Moreover, the materials, transportation, and heavy equipment used in construction were optimized.

\section{Methodology}

A quantitative method was applied in this research to calculate the energy consumption of each activity based on the phases including initiation, design, construction, and operation in the project life cycle. The study was conducted base on 3 bridge projects located in Central Java as case studies and presented in the figure 5 . The first case study is the Ganefo Bridge Construction Project in Galeh Ngrampal, Sragen, the second is the Jagung Bridge Construction Project, Kajen, Pekalongan, and the third is the Miri Bridge Construction Project, Purwantoro, Wonogiri. The detailed description of these projects is shown in table 2. 


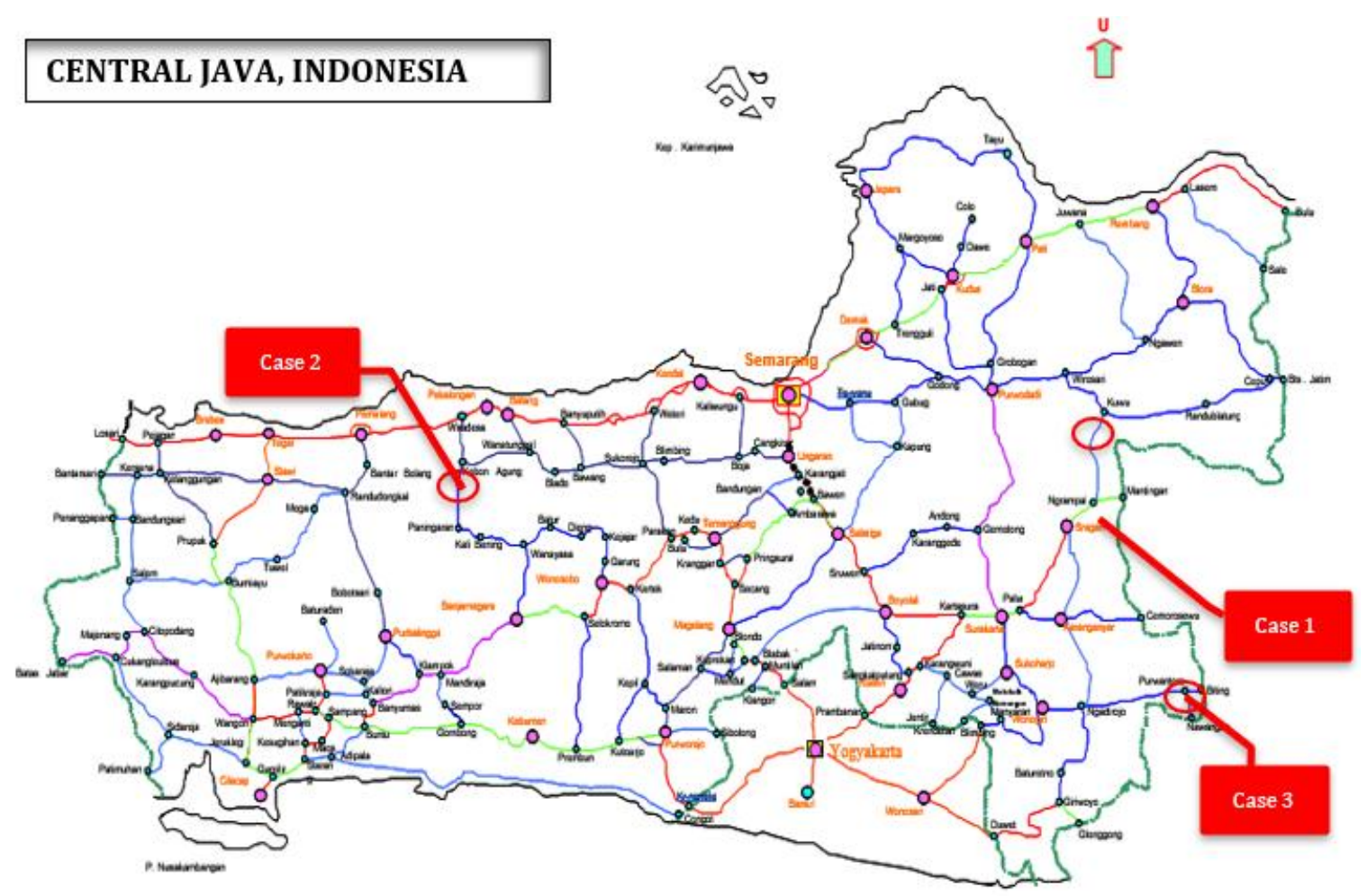

Figure 5. Research Location in Central Java, Indonesia

Table 2. The Project Data Information

\begin{tabular}{|c|c|c|c|}
\hline Description & \multicolumn{3}{|c|}{ Research Data Information } \\
\hline $\begin{array}{c}\text { Name of } \\
\text { Project }\end{array}$ & $\begin{array}{c}\text { Ganefo } \\
\text { Bridge }\end{array}$ & Jagung Bridge & Miri Bridge \\
\hline Location & Sragen & Pekalongan & Wonogiri \\
\hline Owner & $\begin{array}{c}\text { Public Work } \\
\text { Department }\end{array}$ & $\begin{array}{c}\text { Public Work } \\
\text { Department }\end{array}$ & $\begin{array}{c}\text { Public Work } \\
\text { Department }\end{array}$ \\
\hline Coordinate & $\begin{array}{c}7^{\circ} 20^{\prime} 05.0^{\prime \prime} \mathrm{S} \\
111^{\circ} 03^{\prime} 28.9^{\prime \prime} \\
\mathrm{E}\end{array}$ & $\begin{array}{c}7^{\circ} 01^{\prime} 21.5^{\prime \prime} \mathrm{S} \\
109^{\circ} 33^{\prime} 01.9^{\prime \prime} \mathrm{E}\end{array}$ & $\begin{array}{c}7^{\circ} 54^{\prime} 36.7^{\prime \prime} \mathrm{S} \\
111^{\circ} 15^{\prime} 00.1^{\prime \prime} \\
\mathrm{E}\end{array}$ \\
\hline Length & $105 \mathrm{~m}$ & $200 \mathrm{~m}$ & $36 \mathrm{~m}$ \\
\hline Width & $7 \mathrm{~m}$ & $7 \mathrm{~m}$ & $6 \mathrm{~m}$ \\
\hline Area & $735 \mathrm{~m}^{2}$ & $1400 \mathrm{~m}{ }^{2}$ & $216 \mathrm{~m}{ }^{2}$ \\
\hline $\begin{array}{c}\text { Basecamp } \\
\text { to location }\end{array}$ & $9.17 \mathrm{~km}$ & $20 \mathrm{~km}$ & $8.73 \mathrm{~km}$ \\
\hline $\begin{array}{c}\text { Type of } \\
\text { Constructio } \\
\mathrm{n}\end{array}$ & $\begin{array}{c}\text { Reinforcemen } \\
\mathrm{t} \text { Concrete }\end{array}$ & $\begin{array}{c}\text { Reinforcement } \\
\text { Concrete }\end{array}$ & $\begin{array}{c}\text { Reinforcemen } \\
\text { t Concrete }\end{array}$ \\
\hline $\begin{array}{c}\text { Type of } \\
\text { Floor Layer }\end{array}$ & Asphalt & Asphalt & Asphalt \\
\hline Case study & 1 & 2 & 3 \\
\hline
\end{tabular}

The amount of material and fuel used by the construction equipment were determined using building quantity data, a budget plan (BQ), technical specifications, and interviews conducted with the owners, consultants, and contractors. Meanwhile, the inventory of embodied energy coefficient (ICE) data from Bath University (ICE version 1.6a) is presented in table 3 [21].
Table 3. Embodied Energy Coefficient Factor [21]

\begin{tabular}{|c|c|c|c|}
\hline \multirow{2}{*}{ Type of Material } & \multicolumn{3}{|c|}{ Embodied Energy Coefficient Factor } \\
\cline { 2 - 4 } & $\mathrm{MJ} / \mathrm{Kg}$ & $\mathrm{MJ} / \mathrm{Litre}$ & $\mathrm{MJ} / \mathrm{Kwh}$ \\
\hline Stone & 1.2 & - & - \\
\hline Steel Bar & 24.6 & - & - \\
\hline Asphalt Pavement & 2.41 & - & - \\
\hline Cement & 4.6 & - & - \\
\hline Aggregate and Sand & 0.1 & - & - \\
\hline Selected Soil & 0.45 & - & - \\
\hline Concrete & 1.24 & - & - \\
\hline Paint & 68 & - & - \\
\hline PVC Pipe & 70.6 & - & - \\
\hline Gasoline & - & 34.6 & - \\
\hline Kerosene & - & 36.7 & - \\
\hline Light Oli & - & 38.2 & - \\
\hline A Heavy Oil & - & 39.1 & - \\
\hline Electric & - & - & 3.6 \\
\hline
\end{tabular}

The formulas in equations 1,2 , and 3 were used to estimate the quantity of energy consumed.

$$
\begin{aligned}
\mathrm{Ee} & =\mathrm{Ve} \times \mathrm{CFCe} \\
\mathrm{Em} & =\mathrm{Vm} \times \mathrm{CF}_{\mathrm{m}} \\
\mathrm{Et} & =\mathrm{Vt} \times \mathrm{CFt}
\end{aligned}
$$

Ee, Em, and Et are the total energy used for electricity, material, and transportation in units of Mega Joule (MJ). Respectively. Meanwhile, $\mathrm{CFe}, \mathrm{CFm}$, and $\mathrm{CFt}$ are energy coefficient factors in line with the type of sources which are electric $(\mathrm{MJ} / \mathrm{Kwh})$, material $\left(\mathrm{MJ} / \mathrm{m}^{3}\right)$, and fuel (MJ/litre). 
Table 4. Measurement Energy efficiency base on energy footprint on site

\begin{tabular}{|c|l|}
\hline Phase & \multicolumn{1}{|c|}{ Energy efficiency based on energy footprint on site } \\
\hline $\begin{array}{c}\text { Initiation } \\
\text { (Owner Office/ Public Work } \\
\text { Department) }\end{array}$ & $\begin{array}{l}\text { Electric Power Reduction - Minimize the number of light Bulbs in the office } \\
\text { Electric Power Reduction - Minimize the use of computers, printers, and copiers } \\
\text { Electric Power Reduction - Minimize the use of air conditioning in the office } \\
\text { Fuel Saving - Minimize the duration of transportation for project site survey activities }\end{array}$ \\
\hline \multirow{3}{*}{$\begin{array}{l}\text { Design } \\
\text { (Consultant) }\end{array}$} & $\begin{array}{l}\text { Electric Power Reduction - Minimize the number of light Bulbs in the office } \\
\text { Electric Power Reduction - Minimize the use of computers, printers, and copiers }\end{array}$ \\
& $\begin{array}{l}\text { Electric Power Reduction - Minimize the use of air conditioning in the office } \\
\text { Fuel Saving - Minimize the duration of transportation for project site survey activities } \\
\text { Fuel Saving - Minimize the duration of transportation during the consultation with owners }\end{array}$ \\
\hline \multirow{2}{*}{$\begin{array}{c}\text { Construction } \\
\text { (Contractor) }\end{array}$} & $\begin{array}{l}\text { Material replacement - Replace cement with fly ash as a filler in the asphalt mixture. } \\
\text { Fuel Saving (truck and heavy equipment transport) - Minimize the distance from the Base camp to } \\
\text { the project site }\end{array}$ \\
\hline Maintenance/ Operational & $\begin{array}{l}\text { Electric power reduction- Minimize the number of light Bulbs for outdoor areas or use solar } \\
\text { electricity and automatically turn off the light sensor } \\
\text { (User) }\end{array}$ \\
& $\begin{array}{l}\text { Material replacement- Replace cement with fly ash as a filler in the asphalt mixture. } \\
\text { Fuel Saving (truck and heavy equipment transport) - Minimize the distance from the Base camp to } \\
\text { the project site. }\end{array}$ \\
\hline
\end{tabular}

Table 5. The Energy Calculation Results on Bridge Projects (MJ)

\begin{tabular}{|c|c|c|c|c|c|c|}
\hline $\begin{array}{c}\text { Cases } \\
\text { Phases }\end{array}$ & \multicolumn{2}{|c|}{ Bridge Project 1 } & \multicolumn{2}{c|}{ Bridge Project 2 } & \multicolumn{3}{c|}{ Bridge Project 3 } \\
\hline Initiation Phase & $639,559.20$ & $3 \%$ & $171,940.20$ & $1 \%$ & $349,784.20$ & $4 \%$ \\
\hline Design Phase & $1,375,191.65$ & $6 \%$ & $850,482.65$ & $5 \%$ & $708,156.43$ & $8 \%$ \\
\hline Construction Phase & $15,528,993.95$ & $71 \%$ & $10,098,839.12$ & $61 \%$ & $6,077,255.67$ & $69 \%$ \\
\hline Operational Phase & $4,326,798.35$ & $20 \%$ & $5,495,379.13$ & $33 \%$ & $1,618,516.39$ & $19 \%$ \\
\hline Total Energy (MJ) & $\mathbf{2 1 , 8 7 0 , 5 4 3 . 1 4}$ & $100 \%$ & $\mathbf{1 6 , 6 1 6 , 6 4 1 . 0 9}$ & $100 \%$ & $\mathbf{8 , 7 5 3 , 7 1 2 . 6 9}$ & $100 \%$ \\
\hline
\end{tabular}

\section{Results and Discussion}

The results of the energy consumed in the bridge project are presented in table 5 .

Table 5 shows the amount of energy consumed in implementing the bridge project. The value at the initiation phase of Project 1 was 639,559.20 MJ, the design phase was $1,375,191.65 \mathrm{MJ}$, while the construction and operational phases were 15,528,993.95 MJ and $4,326,798.35$ MJ respectively. In bridge project 2 , the value at the initiation phase was $171,940.20 \mathrm{MJ}$, the design phase was $850,482.65 \mathrm{MJ}$ while the construction and operational phases were $10,098,839.12$ MJ and $5,495,379.13$ MJ respectively. Meanwhile, the value for bridge project 3 at the initiation phase was $349,784.20 \mathrm{MJ}$, the design phase was $708,156.43 \mathrm{MJ}$ while the construction and operational phases were 6,077,255.67 $\mathrm{MJ}$ and 1,618,516.39 MJ respectively.

Figure 6 reveals the percentage of embodied energy consumption in each project based on the phases of activities and the initiation phase was found to be $<5 \%$, design phase was between 5\% - 8\% o, construction phase was the highest with an average of $60 \%-70 \%$ while the operational phase was 19\% - 33\% of total energy.

Table 6 showed the reduction in consumption after optimization and bridge project 1 was reduced in the initiation phase by $255,358.32 \mathrm{MJ}(1.17 \%)$, design phase by $322,472 \mathrm{MJ}(1.47 \%)$, the construction phase was $505,062.07 \mathrm{MJ}(2.31 \%)$, and operational phase was $350,420.42 \mathrm{MJ}(1.60 \%)$ while the total energy reduction was recorded to be $1,433,312.80 \mathrm{MJ}(6.55 \%)$ of the initial value. In bridge project 2 , the reduction in the initiation phase was $1,048.32 \mathrm{MJ}(0.01 \%)$, the design phase was 209,674.80 MJ (1.26\%), construction was 999,767.70 MJ (6.02\%), and the operational phase was 240,716.81 MJ $(1.45 \%)$ while the total energy was reduced by $1,451,207.63 \mathrm{MJ}(8.73 \%)$ of the initial energy consumed. In the bridge project 3 , the amount of energy reduction at the initiation phase was $1,048.32 \mathrm{MJ}(0.01 \%)$, the design phase was 25,084.20 MJ (0.29\%), while each of the construction and operational phases were 130,230.42 MJ $(1.49 \%)$ and $145,590.09 \mathrm{MJ}(1.66 \%)$ respectively with a total energy reduction recorded to be $301,953.03 \mathrm{MJ}$ $(3.45 \%)$ of initial energy consumed. The comparison of the energy consumed before and after energy optimization is presented in figure 7 and 8. 


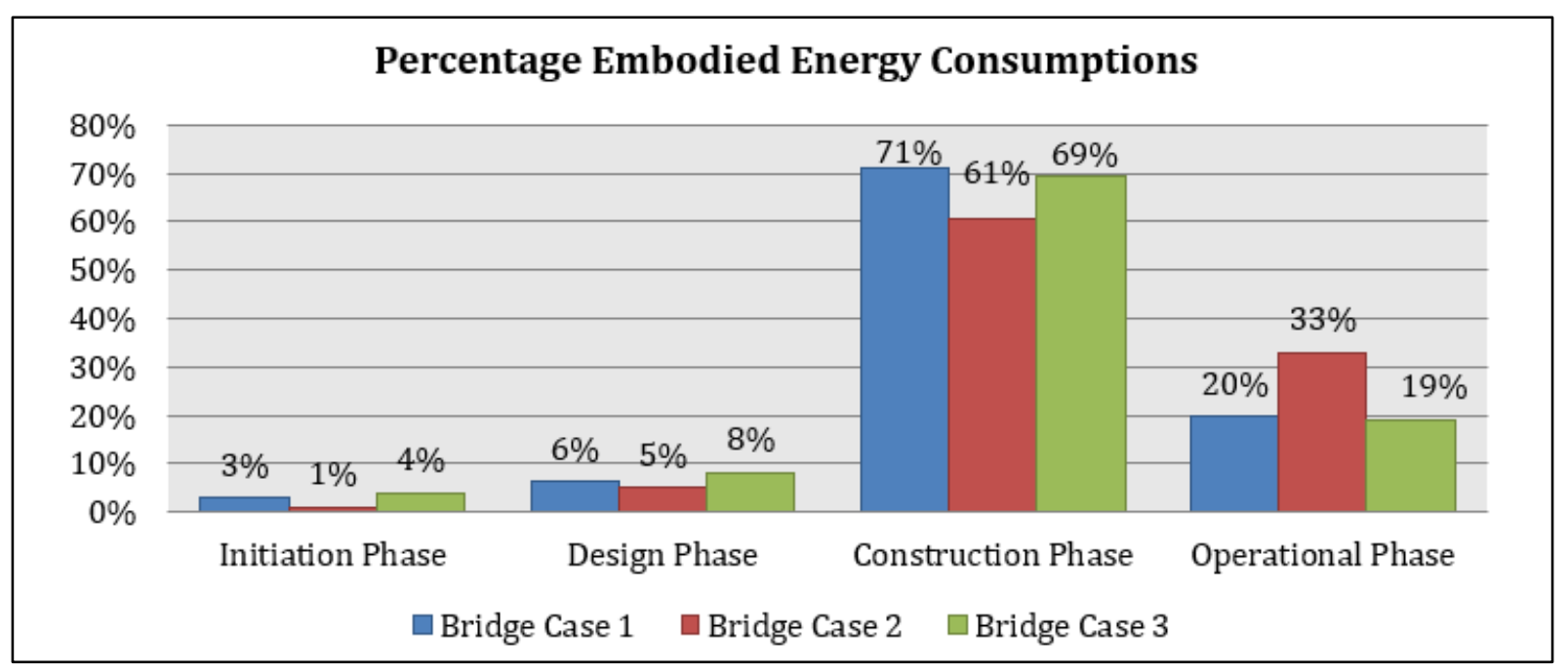

Figure 6. Percentage of Embodied Energy Consumptions

Table 6. Results of Reducing Energy Consumption in Bridge Projects after Optimization (MJ)

\begin{tabular}{|c|c|c|c|c|c|c|}
\hline $\begin{array}{c}\text { Cases } \\
\text { Phases }\end{array}$ & \multicolumn{2}{|c|}{ Bridge Project 1 } & \multicolumn{2}{c|}{ Bride Project 2 } & \multicolumn{2}{c|}{ Bridge Project 3 } \\
\hline Initiation Phase & $255,358.32$ & $1,17 \%$ & $1,048.32$ & $0,01 \%$ & $1,048.32$ & $0,01 \%$ \\
\hline Design Phase & $322,472.00$ & $1,47 \%$ & $209,674.80$ & $1,26 \%$ & $25,084.20$ & $0,29 \%$ \\
\hline Construction Phase & $505,062.07$ & $2,31 \%$ & $999,767.70$ & $6,02 \%$ & $130,230.42$ & $1,49 \%$ \\
\hline Operational Phase & $350,420.42$ & $1,60 \%$ & $240,716.81$ & $1,45 \%$ & $145,590.09$ & $1,66 \%$ \\
\hline Total Energy (MJ) & $\mathbf{1 , 4 3 3 , 3 1 2 . 8 0}$ & $6,55 \%$ & $\mathbf{1 , 4 5 1 , 2 0 7 . 6 3}$ & $8,73 \%$ & $\mathbf{3 0 1 , 9 5 3 . 0 3}$ & $3,45 \%$ \\
\hline
\end{tabular}

\section{Percentage Reducing Embodied Energy After Optimization}

$\square$ Bridge Case $3 \quad \square$ Bridge Case $2 \quad \square$ Bridge Case 1

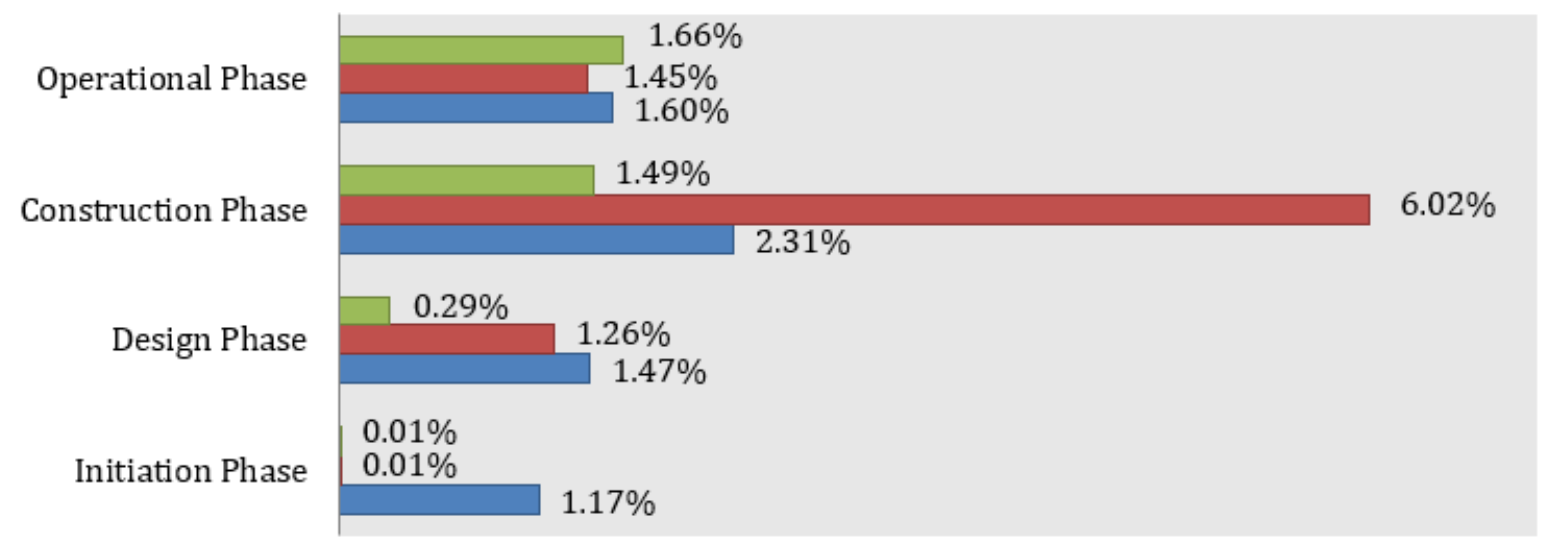

Figure 7. The Percentage Reducing of Embodied Energy Consumptions 


\section{ENERGY COMSUMPTION BEFORE \& AFTER OPTIMIZATION}

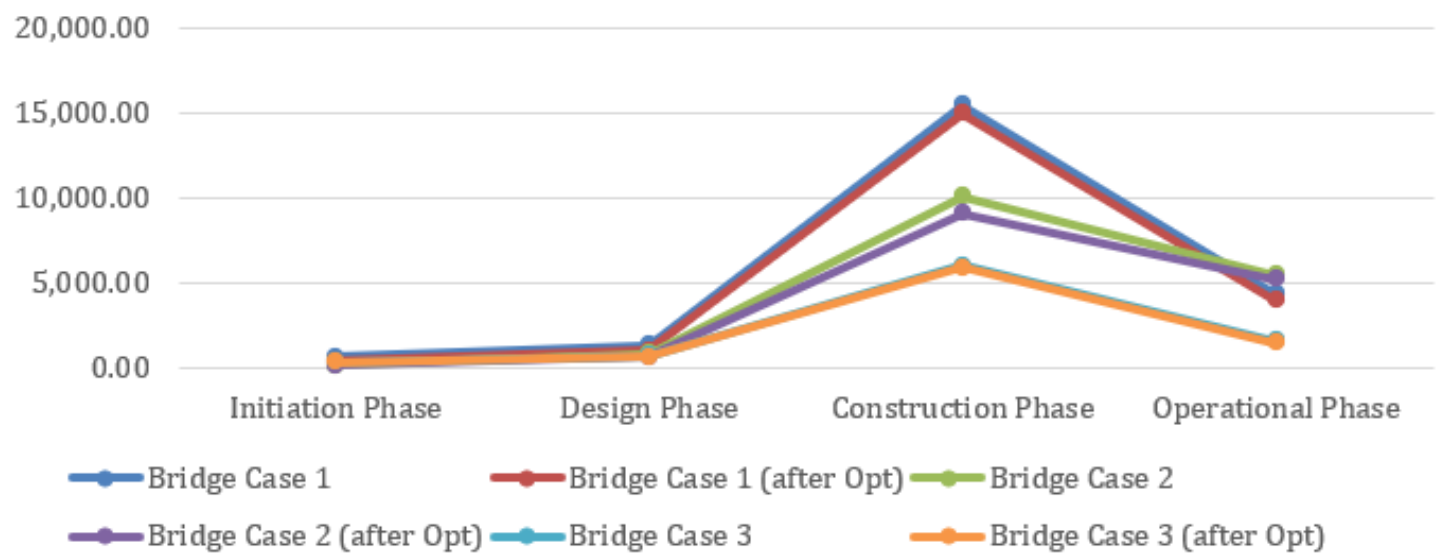

Figure 8. Embodied Energy Consumption before and after Optimization.

Table 7. Total Embodied Energy Based on Building Area

\begin{tabular}{|c|c|c|c|c|c|}
\hline & \multicolumn{2}{|c|}{ Total Energy (MJ) } & \multirow{2}{*}{$\begin{array}{l}\text { Area } \\
\left(\mathrm{m}^{2}\right)\end{array}$} & \multicolumn{2}{|c|}{ Total Energy per Area $\left(\mathrm{MJ} / \mathrm{m}^{2}\right)$} \\
\hline & Before Optimization & After Optimization & & Before Optimization & After Optimization \\
\hline Bridge Case 1 & $21,870,543.14$ & $20,437,230.34$ & 735 & $29,755.84$ & $27,805.76$ \\
\hline Bridge Case 2 & $16,616,641.09$ & $15,165,433.46$ & 1400 & $11,869.03$ & $10,832.45$ \\
\hline Bridge Case 3 & $8,753,712.69$ & $8,451,759.66$ & 216 & $40,526.45$ & $39,128.52$ \\
\hline
\end{tabular}

Figure 7 reveals the percentage of embodied energy minimized through optimization and also that the Bridge 2 was observed to have a significant reduction in the construction phase due to the optimization of the distance of the base camp to the project site from $40 \mathrm{~km}$ to $5 \mathrm{~km}$. This subsequently reduced the transportation cost of fuel, materials, and tools.

Figure 8 shows the construction phase consumed the largest amount of embodied energy followed by the operational and design phase while the least was recorded at the initiation stage. The high consumption was associated with the use of materials such as cement, steel, and fuel in heavy equipment and transportation. The optimization was achieved by prioritizing materials with low embodied energy and using environmentally friendly heavy equipment. The energy calculated is, therefore, expected to be used as an evaluation tool by stakeholders, consultants, contractors, and building managers to further minimize the energy consumed by each of the activities.

Table 7 and Figure 9 shows the amount of energy consumption expended per area on the bridge building and the values before and after optimization for Bridge Case 1 was $29,755.84 \mathrm{MJ} / \mathrm{m}^{2}$ and $27,805.76 \mathrm{MJ} / \mathrm{m}^{2}$, Bridge Case 2 was $11,869.03 \mathrm{MJ} / \mathrm{m}^{2}$ and $10,832.45 \mathrm{MJ} / \mathrm{m}^{2}$ while Bridge Case 3 was 40,524.45 MJ / $\mathrm{m}^{2}$ and 39,128.52 MJ / $\mathrm{m}^{2}$ respectively. The highest energy was consumed in bridge case 3 despite having the smallest area of $216 \mathrm{~m}^{2}$. This, therefore, means a small building area has an influence on energy consumption.

The largest percentage of energy reduction was in Bridge Case 2 with $9 \%$ followed by Bridge Case 2 with $7 \%$ while the least, $3 \%$, was found in Bridge Case 3 as shown in Figure 10. The energy consumption limits on the average construction phase per- building area has been reported by a previous study to be $5.754 \mathrm{MJ} / \mathrm{m}^{2}$ [22] while the average operational phase was between $290 \mathrm{MJ} / \mathrm{m}^{2}-1,210 \mathrm{MJ} / \mathrm{m}^{2}$ $[23,24,25,26]$. Meanwhile, the energy consumption during the bridge case construction phase 1, 2, and 3 was $21,127.88 \mathrm{MJ} / \mathrm{m}^{2}, 7,213.46 \mathrm{MJ} / \mathrm{m}^{2}$, and $28,135.44 \mathrm{MJ} / \mathrm{m}^{2}$ while the operational phase was recorded to have consumed 5,866.80 MJ/m², 3,925.27 MJ/m², and 7,493.13 $\mathrm{MJ} / \mathrm{m}^{2}$ respectively. The energy consumed in these two phases was observed to be greater than the average limit, there, optimization and minimization were required. 


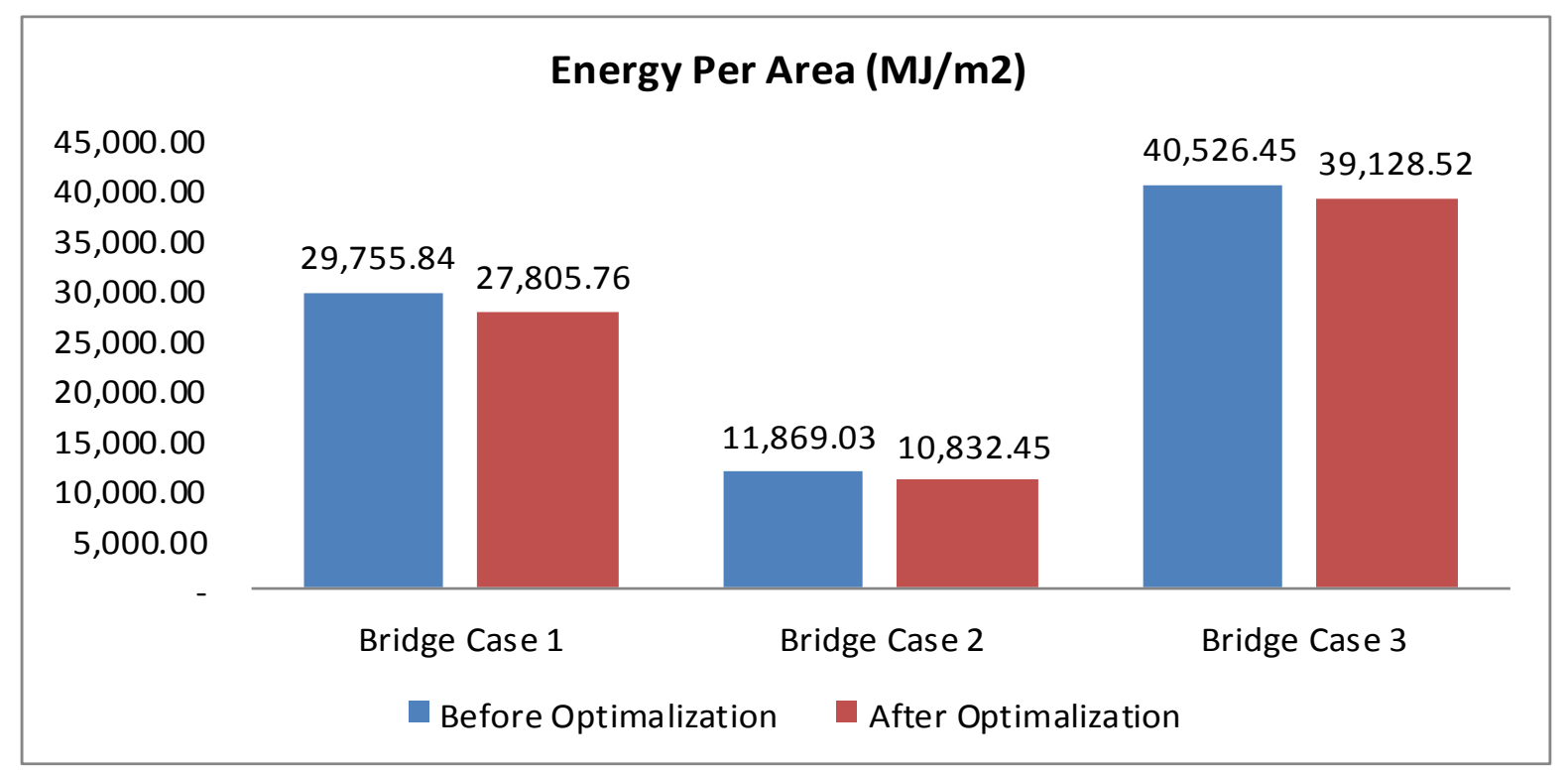

Figure 9. Total Embodied Energy Per- Building Area

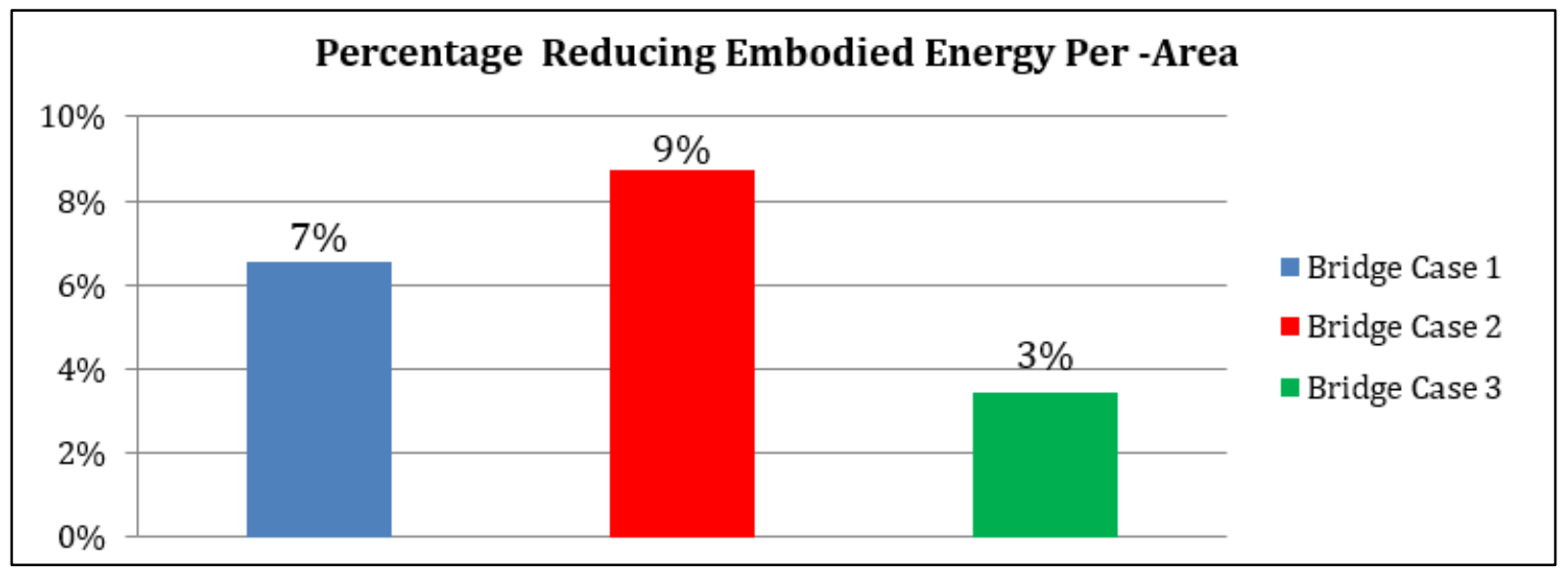

Figure 10. The Percentage of Reducing Embodied Energy Per-Building Area

\section{Conclusion}

Indonesia is an archipelagic country which geographically has many large rivers spread across all the islands and this means it needs bridges to form road networks to connect the regions. The construction of these bridges depends on the existing conditions of the area as well as the aesthetic aspects which determine the type of the structure either concrete or steel frame to be used.

The findings of this research showed the energy consumption in Bridge Cases 1, 2, and 3 was 21,870,543.14 MJ, 16,616,641.09 MJ, and 8,753,712.69 MJ and reduced by $1,433,312.80 \mathrm{MJ}(6.55 \%)$, $1,451,207.63 \mathrm{MJ}(8.73 \%)$, and 301,953.03MJ (3.45\%) after optimization, respectively. Meanwhile the expended area was $29,755.84 \mathrm{MJ} / \mathrm{m}^{2}, 11,869.03 \mathrm{MJ} / \mathrm{m}^{2}$, and $40,524.45$ $\mathrm{MJ} / \mathrm{m}^{2}$ with a decrease of $7 \%, 9 \%$, and $3 \%$ respectively after optimization. Therefore, the optimization of energy consumption in each phase through efficient use of electricity, materials, and fuels for transportation as well as the selection of environmentally friendly construction tools have the ability to reduce energy consumption and emissions produced during the building's life cycle.

\section{Acknowledgments}

The authors show gratitude to the Department of Public Works of Central Java Province and the Doctoral Program of Faculty of Engineering of Diponegoro University, Indonesia.

\section{REFERENCES}

[1] UNFCCC, The Paris Agreement: Conference of the Parties Twenty-first session Paris, 2016, Online available from https://unfecc.int 
[2] UNEP, Global Status Report for Buildings and Construction Sector: Towards a zero-emission, efficient and resilient buildings and construction sector, 2019. Online available from https://www.unenvironment.org

[3] O. Tatsuo, K. Yokoyama, S.Takao, N.Yokoo, and M.Yamamoto, Introduction of Annex 57 - Evaluation of Embodied Energy and Carbon Dioxide Emissions for Construction Worldwide, World SB 14 Barcelona Conference, Spain, 26-32, 2014.

[4] GABC, the Global Status Report: Towards a zero emission, efficient and resilient buildings, and construction sector, 2017, Online available fromhttps://www.Unenvironment.or $\mathrm{g}$

[5] GBCI, Greenship Assessment Tool For New Buildings Version 1.2, 2018. Online available from http://www.gbcindonesia.org

[6] F Baró, R Bugter, E Gómez-Baggethun, J Hauck, L Kopperoinen, C Liquete, M Potschin, Green Infrastructure, Openness Synthesis Paper, Vol.1, No. 13, 1-7, 2015.

[7] M Marzouk, A Nouh, M El-Said, Developing green bridge rating system using Simos'procedure, Housing and Building National Research Center (HBRC) Journal, Vol. 10, 176 $182,2014$.

[8] L.B Cole, T McPhearson, C.P Herzog, A Russ, Green Infrastructure Journal, Vol. 27, 261- 270, 2017.

[9] BPS-Statistics Indonesia, Construction in Figures 2019, Online available from http://www.bps.go.id

[10] P. Fuertes, Embodied Energy Policies to Reduce Existing Buildings, International Conference-Alternative and Renewable Energy Quest, AREQ 2017, Spain, Energy Procedia,115, pp. 431-439, 2017.

[11] G.D.Oberlender Project Management For Engineering And Construction Third Edition, McGraw-Hill Education, USA, pp. 31-288, 2014.

[12] M. Balouktsi \& T.Lützkendorf, Energy efficiency of buildings: the aspect of embodied energy, Energy Technology: Special Issue: Energy, Science \& Technology Conference, 4 (1), pp. 31-43, 2016.

[13] T. Ramesh., Prakash R., Shukla K.K. Life cycle energy analysis of buildings: an overview, Energy and Buildings, 42, pp. 1592-1600, 2010.

[14] D Bennett, G Parke, N Hewson, ICE Manual of Bridge
Engineering, the history and aesthetic development of bridges, ICE Publishing is a division of Thomas Telford Ltd, London, 2008.

[15] M.S Troitsky, Planning and Design of Bridges 1st Edition, John Wiley \& Sons, Inc., New York, 1994.

[16] J. Radic, M Kuster \& B Kincl, Structural - Architectural Approach to Bridge Design, Large Structures and Infrastructures for Environmentally Constrained and Urbanized Areas, IABSE Symposium Report, Vol.97, No.22, $8-15,2010$.

[17] W.F Chen and L Duan, Bridge Engineering Handbook, CRC Press LLC, USA, 2000.

[18] British Standards Institution, BSEN 15978, Sustainability of Construction Works Assessment of Environmental Performance of Buildings - Calculation Method, British Standards Institution, London, UK, 2011.

[19] Goggins J., Keane T., Kelly A. The assessment of embodied energy in typical reinforced concrete building structures in Ireland, Energy and Buildings, 42, pp. 735 - 744, 2010.

[20] Wibowo M.A, Uda S.A.K.A. and Zhabrinna, Reducing carbon emission in construction base on project life cycle (PLC), MATEC Web of Conferences 195, 06002, pp. 1-11, 2018 ,

[21] G Hammond \& C Jones, Embodied Energy and Carbon in Construction Materials, Energy, Vol. 161, No.2, 87-98, 2008.

[22] A Cuchí, G Wadel, F Lopez and A Sagrera, Guía de la Eficiencia Energética Para Los Administradores de Fincas, Fundación Gas Natural Ltd, Spain, 2007.

[23] BOMA, Energy Guidelines, Building Owners and Managers Association, Melbourne,1994.

[24] R. Jaques, Energy efficiency building standards project review of embodied energy, Proceedings of the Embodied Energy: the current state of play Seminar, School of Architecture and Building, Deakin University, Geelong, 51-60, 1996.

[25] M Suzuki, and T Oka, Estimation of life cycle energy consumption and $\mathrm{CO} 2$ emission of office buildings in Japan', Energy and Buildings, Vol. 28, 33-41, 1998.

[26] P.Crowther, Design for disassembly to recover embodied energy, The 16th annual conference on passive and low energy architecture, Melbourne-Brisbane-Cairns, Australia, 95-100, 1999. 